\title{
MODEL EVALUASI LAYANAN AIR MINUM DI DKI JAKARTA
}

\author{
Samadi1) dan Suhardjo2) \\ 1), 2) Dosen Jurusan Geografi FIS UNJ \\ Email: adinote@gmail.com
}

\begin{abstract}
ABSTRAK
Tujuan penelitian adalah mengkonstruksi model layanan air bersih (air minum) di DKI Jakarta khususnya untuk parameter kontinuitas pelayanan 24 jam. Metode penelitian menggunakan metode kualitatif. Populasi dan sampel penelitian terdiri dari masyarakat pelanggan air PAM di wilayah Timur Jakarta sebanyak 499 responden serta pihak pengelola (perusahaan) air bersih PT. AETRA. Sampel dipilih berdasarkan teknik purpossive sampling. Teknik pengumpulan data melalui wawancara langsung dengan bantuan panduan wawancara. Disamping itu, data primer juga diperoleh melalui proses FGD (focus groups discussion). Instrumen penelitian menggunakan panduan wawancara dan panduan umum diskusi untuk pelaksanaan Focus Group Discussion. Data terolah dianalisis melalui system dinamik.

Hasil penelitian menunjukkan bahwa : (1) Faktor-faktor yang berpengaruh terhadap peningkatan kontinuitas layanan air minum di DKI Jakarta adalah jumlah penduduk, tarif air bersih, kapasitas terpasang, tingkat kehilangan air, dan kuantitas air baku. (2) Model dinamika kontinuitas layanan air minum di DKI Jakarta dapat disusun dari tiga aspek, yaitu aspek-aspek pelanggan, kapasitas pengolahan, danpasokan air. Faktor-faktor penduduk dan tarif dapat digolongkan kedalam sub model pelanggan. Faktor-faktor kapasitas terpasang dan tingkat kehilangan air dapat digolongkan kedalam sub model kapasitas pengolahan. Sementara faktor kuantitas air baku dapat digolongkan kedalam sub model pasokan air.
\end{abstract}

\section{Kata kunci : Model Evaluasi, Kontinuitas layanan air minum, DKI Jakarta.}

\section{PENDAHULUAN}

Kota Jakarta adalah kawasan yang membentang di wilayah pesisir dan pesisir pada hakikatnya merupakan kawasan paling produktif terlebih berbagai aktivitas ekonomi mengambil tempat di sini. Dan sebagai kawasan yang terus berkembang, kota Jakarta juga terus mengalami tekanan baik disebabkan oleh pertumbuhan penduduk, perubahan penggunaan lahan, maupun penurunan kualitas sumber daya pesisir, dan penurunan kualitas air relatif rentan terhadap perubahan kawasan akibat tumbuhnya wilayah permukiman secara cepat yang biasanya dipicu oleh pertumbuhan industri. Dua kawasan permukiman dan industri biasanya juga memerlukan air bersih relatif besar, baik yang diperoleh dari suplai air bersih sistem perpipaan (air PAM) maupun melalui pemompaan air tanah.

Meningkatnya proporsi dari populasi dalam penggunaan sumber air minum layak akan mecerminkan persentase penduduk yang menggunakan salah satu sumber air bersih berikut: air ledeng ke rumah tinggal, plot atau halaman, hidran umum, sumur bor, sumur gali, mata air terlindung, penampungan air hujan dan 
air minum kemasan (jika sumber sekunder yang tersedia adalah juga meningkat); dan jika konsumsi semakin tinggi, bisa saja penyediaan air bersih penduduk harus diupayakan bersumber dari air gerobak, tanki air dari mobil, air permukaan (langsung dari sungai, kolam, sungai, danau, waduk atau irigasi saluran) yang sudah diolah terlebih dahulu (Ali Karnib, 2015).

Terkait penggunaan sumber sekunder tersebut di atas, bisa saja dikembangkan dengan memperhatikan cara-cara paling efektif dan secara konsisten memastikan keselamatan pasokan air minum (Gabriella Lockhart, William E. Oswald, Brian Hubbard, Elizabeth Medlin, and Richard J. Gelting, 2012; WHO, 2011) dan melalui pengolahan serta pengelolaan secara standar dan dapat dievaluasi di seluruh dunia (Gelting RJ, Delea K, Medlin E., 2012). Dan karenanya, beberapa pendekatan untuk menentukan model evaluasi dan pemenuhan air bersih penduduk di kawasan perkotaan dapat menggunakan pendekatan analisis regresi spasial dengan Geographically Weighted Regresion (Rulli Pratiwi Setiawan, 2014), metode Goal Programming, metode pemodelan dinamika system, Model Partnership, dan berbagai pendekatan lain yang sesuai dengan kondisi eksisting pelayanan serta karakter masyarakatnya.

Pendekatan-pendekatan tersebut di atas dipandang mampu mengevaluasi dan meningkatkan kontinuitas layanan air minum sebagai efek positif dari rencana keselamatan air tanpa memerlukan pengawasan yang luas, studi dan waktu yang relative lebih lama guna membantu meningkatkan perbaikan kualitas air dan kesehatan masyarakat (Gelting RJ, Delea K, Medlin
E., 2012) sesuai dengan karakteristik permasalahan yang dihadapi.

Permasalahan yang dihadapi oleh penyelenggara pengelolaan air bersih DKI Jakarta sangatlah kompleks, mulai dari terbatasnya ketersediaan dan suplai air baku, peningkatan kebutuhan (demand), cakupan layanan yang masih relatif rendah, tingginya angka kehilangan air, masih rendahnya standar pelayanan, dan sampai adanya tuntutan terhadap kebijakan pembatasan ekstraksi air tanah dalam (deep groundwater).

Masalah lain seperti beragamnya latar belakang konsumen (ekonomi, pendidikan, dan sebagainya), keinginan serta kemampuan membayar harga air, kebocoran, dan atau pencurian air; menjadikan perusahaan air PAM kadang-kadang memberikan prioritas pelayanan kepada konsumen bisnis utamanya terhadap segmen industri. Dan bagi konsumen rumah tangga/domestik, masalah di atas seringkali menimbulkan masalah terhadap pola distribusi aliran yang mereka rasakan. Perbedaan pelayanan tersebut bisa saja dimungkinkan oleh kepentingan perusahaan untuk memenuhi target pelayanan dan pencapaian keuntungan perusahaan untuk kelancaran usahanya. Kesemua permasalahan di atas pada akhirnya mengharapkan solusi yang bisa dengan segera diwujudkan.

Kontinuitas adalah salah satu unsur penting dimana pelayanan yang baik adalah yang mendapatkan pelayanan secara penuh 24 jam terus menerus. Kontinuitas mencerminkan baiknya pengelolaan air bersih secara teknis operasional. Dengan mengetahui posisi pelayanan 24 jam di wilayah DKI Jakarta, dapat dijadikan dasar untuk membantu menetapkan prioritas tingkat 
pelayanan. Dan berdasarkan hasil penelitian di tahun pertama sebelumnya, dimana telah diperoleh Peta Distribusi Layanan air bersih baik yang masuk kedalam kategori 24 jam full terlayani maupun tidak terlayani 24 jam, maka penelitian di tahun kedua ini adalah untuk mengkonstruksi model evaluasi dan peningkatan kontinuitas layanan air minum di DKI Jakarta, sehingga bisa mendorong peningkatan kualitas layanan terhadap kebutuhan air bersih bagi masyarakat.

\section{METODOLOGI PENELITIAN}

Tujuan penelitian adalah mengkonstruksi model layanan air bersih (air minum) di DKI Jakarta khususnya untuk parameter kontinuitas pelayanan 24 jam, sehingga bisa mendorong peningkatan kualitas layanan terhadap kebutuhan air bersih bagi masyarakat. Metode penelitian di tahun kedua menggunakan kualitatif. Populasi dan sampel penelitian terdiri dari masyarakat pelanggan air PAM di wilayah Timur Jakarta sebanyak 499 responden serta pihak pengelola (perusahaan) air bersih PT. AETRA. Sampel dipilih berdasarkan teknik purpossive sampling.

Teknik pengumpulan data di tahun kedua dikumpulkan melalui wawancara langsung dengan bantuan panduan wawancara. Disamping itu, data primer juga diperoleh melalui proses FGD (focus groups discussion). Instrumen penelitian di tahun kedua menggunakan panduan wawancara dan panduan umum diskusi untuk pelaksanaan Focus Group Discussion. Data terolah pada tahun kedua dianalisis melalui system dinamik.

\section{HASIL DAN PEMBAHASAN Peta Distribusi Air Mengalir 24 Jam dan Bukan 24 Jam di Timur Jakarta Berdasarkan penelitian tahun sebelumnya, yang menghasilkan peta distribusi layanan, khususnya untuk parameter kontinuitas pelayanan 24 jam; menunjukkan bahwa kualitas Air PAM di wilayah penelitian memiliki angka survey tertinggi pada selalu jernih sebanyak 71 , $34 \%$ atau 356 responden. Diikuti dengan kondisi kadang keruh 27, $86 \%$ atau 139 responden. Serta kondisi air PAM yang sering keruh sebanyak 0,80 $\%$ atau hanya 4 responden. Dengan demikian, hal tersebut mengindikasikan bahwa perusahaan pengelola air bersih dalam hal ini PT. Aetra rata-rata memiliki Kualitas Air yang selalu Jernih.}




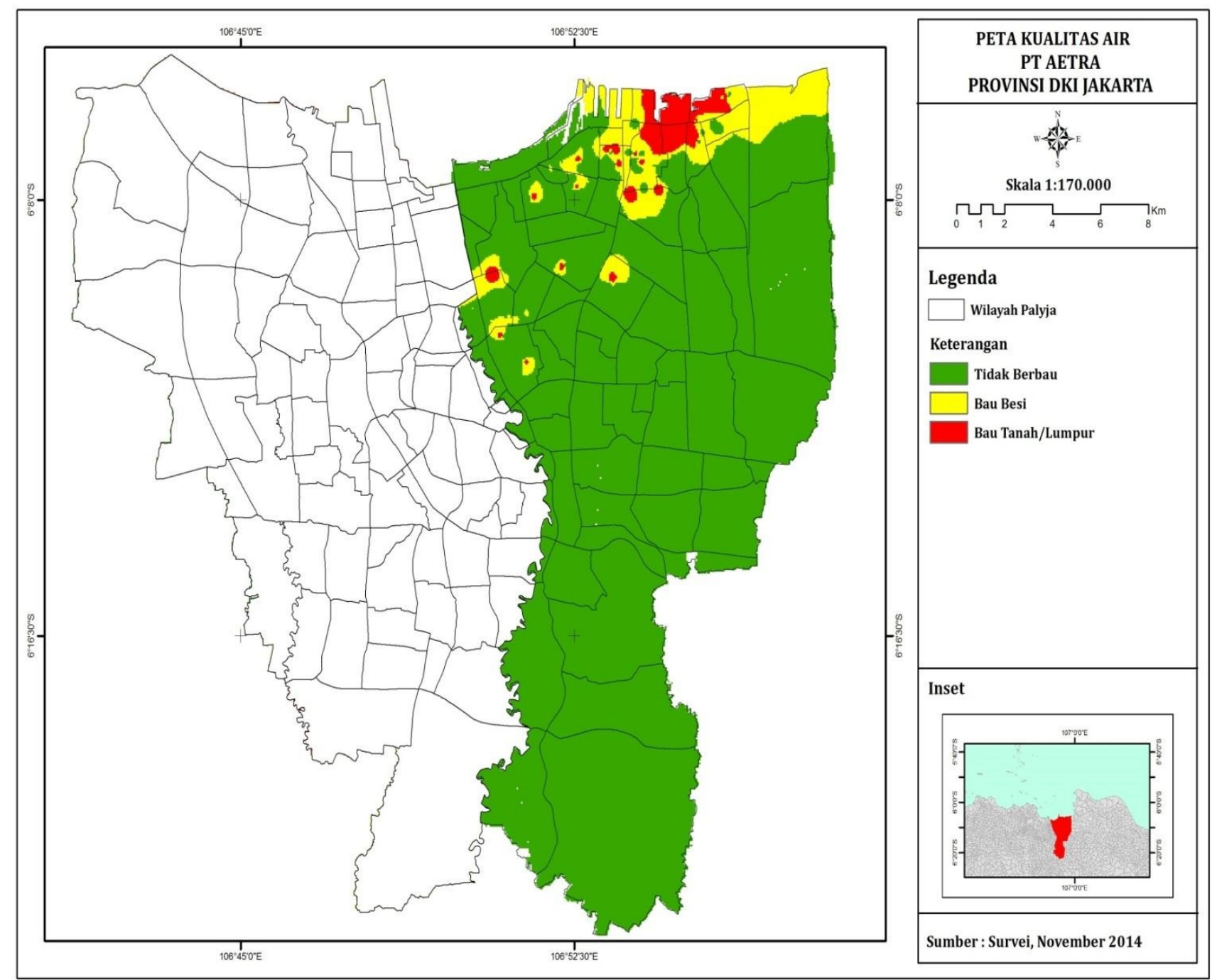

Gambar 1. Peta Kualitas (Keluhan) Air PAM di PT. Aetra

Sedangkan rata-rata air mengalir dalam sehari di lokasi penelitian memiliki angka tertinggi pada rata-rata air mengalir 24 jam dengan 301 responden atau $60,32 \%$. Diikuti dengan rata-rata air mengalir 12-23 jam dengan 120 responden atau dengan 24, $05 \%$ memiliki air rata-rata $0-12$ jam dalam sehari dan 78 responden atau dengan $15,63 \%$ memiliki air rata-rata $12-23$ jam dalam sehari. Dan terpenting, penelitian ini menghasilkan sebuah peta distribusi layanan, khususnya untuk parameter kontinuitas pelayanan 24 jam pada lokasi penelitian. 


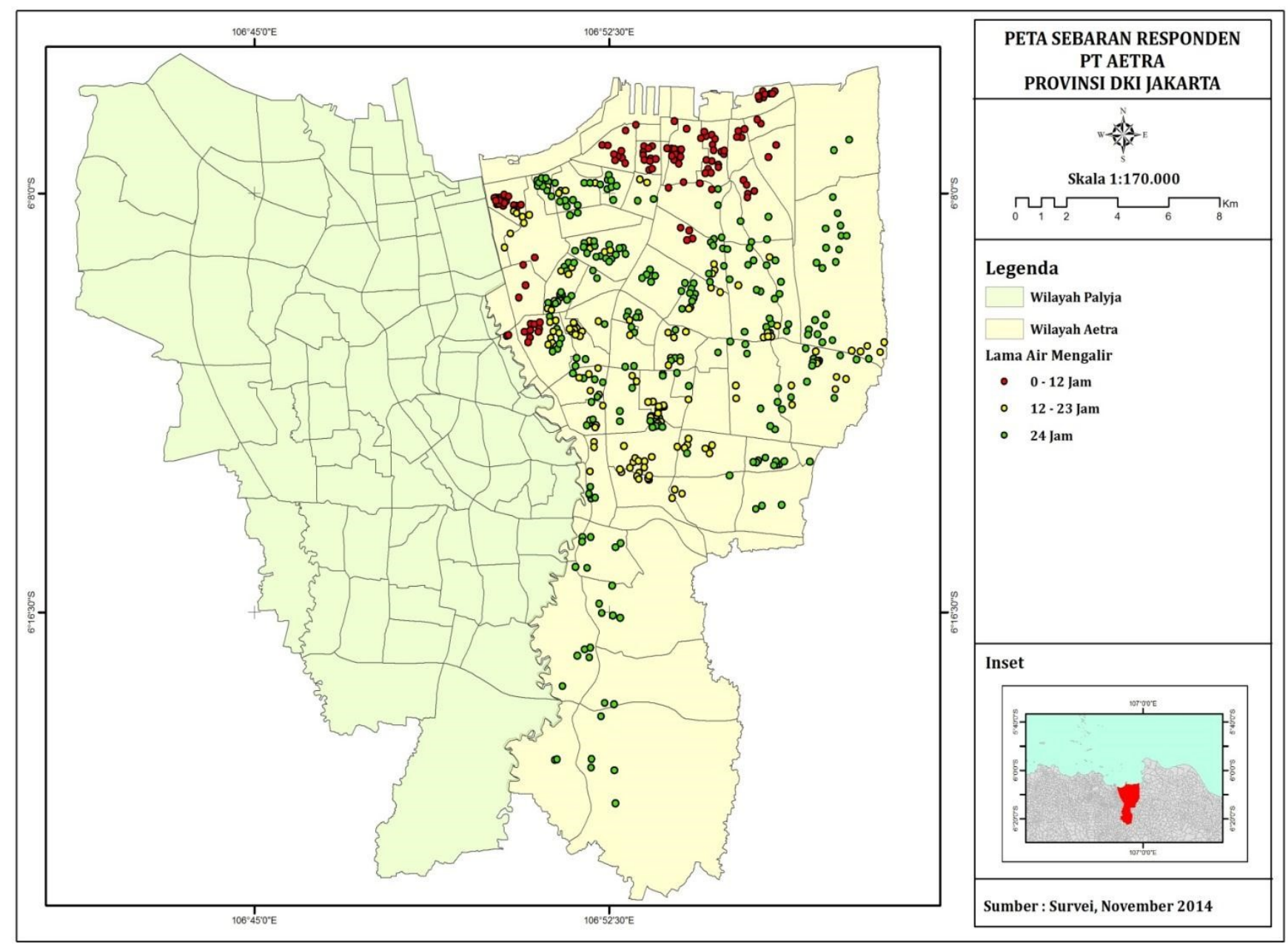

Gambar 2. Peta Sebaran Responden berdasarkan rata-rata air mengalir

\section{Kontinuitas Pelayanan Air PAM bagi Pelanggan}

Efektivitas perusahaan pengelola air akan terlihat dari distribusi aliran kebutuhan air bagi masyarakat pengguna maupun pada kualitas dan kuantitas air yang dihasilkan. Kenyataan ini mengakibatkan alokasi sumberdaya air menjadi tidak efisien dan tidak ada insentif untuk melakukan konservasi bagi kelestarian sumberdaya tersebut. Pemakaian air yang berlebihan utamanya air tanah pada akhirnya menimbulkan masalah bagi persediaan air bersih. Kelangkaan air secara fisik disebabkan oleh peningkatan pemakaian air mengikuti laju pertambahan jumlah penduduk, sedang persediaannya semakin menipis karena berbagai faktor seperti kerusakan sistem perlindungan air maupun permintaan agregat terhadap sumberdaya air melebihi laju pemulihannya kembali. Kelangkaan ekonomi ditandai dengan semakin tingginya harga air karena penawaran air lebih rendah dari permintaannya di samping biaya marjinal pemanfaatan air lebih tinggi dari penerimaan marjinalnya. Sumberdaya air merupakan common resources atau bersifat non exclusive 
right sering berhadapan dengan masalah-masalah inefisiensi dalam pengelolaan dan pemanfaatannya.

Berdasarkan hasil penelitian di tahun pertama (tahun 2015), menunjukkan bahwa kualitas Air PAM di wilayah penelitian memiliki angka survey tertinggi pada selalu jernih sebanyak 71 , $34 \%$ atau 356 responden. Diikuti dengan kondisi kadang keruh 27, $86 \%$ atau 139 responden. Serta kondisi air PAM yang sering keruh sebanyak 0,80 $\%$ atau hanya 4 responden. Dengan demikian, hal tersebut mengindikasikan bahwa perusahaan pengelola air bersih dalam hal ini PT. Aetra rata-rata memiliki Kualitas Air yang selalu Jernih. Sedangkan rata-rata air mengalir dalam sehari di lokasi penelitian memiliki angka tertinggi pada rata-rata air mengalir 24 jam dengan 301 responden atau 60, 32 $\%$. Diikuti dengan rata-rata air mengalir 12-23 jam dengan 120 responden atau dengan $24,05 \%$ memiliki air rata-rata 0 12 jam dalam sehari dan 78 responden atau dengan 15, $63 \%$ memiliki air ratarata $12-23$ jam dalam sehari.

Kenyataan di atas memerlukan aktivasi peran yang lebih besar stakeholder demi terbukanya alternatifalternatif pengembangan strategi perluasan distribusi dan pelayanan prima kepada penduduk. Bahwa masih adanya penduduk yang menggunakan air tanah bisa saja diasumsikan bahwa tingkat pemenuhan air minum kepada penduduk relatif masih belum memuaskan.

\section{Analisis Faktor Sebab Akibat}

\section{Pelayanan Air Bersih di Jakarta}

Berdasarkan analisis mendalam dan wawancara terstruktur, ketersediaan air bersih perpipaan ditentukan oleh berbagai faktor-faktor permintaan dan penyediaan air bersih. Dari sisi permintaan, ketersediaan air bersih perpipaan dipengaruhi oleh pertumbuhan penduduk. Hal tersebut lebih jauh lagi dapat dipengaruhi oleh kelahiran, kematian, dan migrasi. Dari sisi penyediaan, ketersediaan air bersih perpipaan dipengaruhi oleh kapasitas pengolahan untuk memasok, menampung, mengolah, dan mendistribusikan air kepada pelanggan. Hal ini lebih jauh lagi juga dipengaruhi ketersediaan dana PDAM. Selain itu, ketersediaan air bersih perpipaan juga dipengaruhi oleh ketersediaan air baku. Hal ini lebih jauh lagi juga dapat dipengaruhi oleh perubahan guna lahan yang terjadi seiring dengan perkembangan wilayah. Hubungan di antara berbagai faktor tersebut bersifat kompleks dan dinamis serta saling mempengaruhi.

Sintesa faktor yang terdiri dari tahap identifikasi berbagai literatur, verifikasi, dan penetapan faktor memberikan hasil bahwa faktor-faktor yang mempengaruhi ketersediaan air bersih perpipaan antara lain jumlah penduduk, tarif air bersih, kapasitas terpasang, kehilangan air, dan kuantitas air baku. Untuk memudahkan analisis, berbagai faktor tersebut digolongkan kedalam beberapa aspek yaitu aspek pelanggan, kapasitas pengolahan, dan pasokan air. Penduduk dan tarif air dapat digolongkan kedalam submodel pelanggan. Kapasitas terpasang dan tingkat kehilangan air dapat digolongkan kedalam submodel kapasitas pengolahan. Sementara kuantitas air baku dapat digolongkan kedalam submodel pasokan air.

\section{Konseptualisasi Model Evaluasi Kontinuitas Layanan Air Minum}

Model evaluasi kontinuitas layanan air minum yang dikembangkan dalam penelitian ini terdiri dari tiga submodel yaitu submodel pelanggan, sumodel kapasitas pengolahan, dan submodel 
pasokan air. Interaksi diantara ketiga submodel menghasilkan tujuh umpan balik yang terdiri dari satu umpan balik positif dan enam umpan balik negatif.

1. Sub model pelanggan

Submodel

pelanggan menunjukkan jumlah pelanggan yang dipengaruhi oleh pertumbuhan penduduk, kesediaan membayar, dan juga ketersediaan air bersih. Kesediaan membayar ditentukan oleh tarif air bersih yang ditetapkan PDAM dan juga besar tarif yang dapat dibayar penduduk (willingness to pay). Tarif air dapat mempengaruhi tingkat konsumsi pelanggan yang juga akan mempengaruhi ketersediaan air. Sementara ketersediaan air merupakan rasio antara volume air terjual dengan volume air yang dibutuhkan. Jumlah penduduk akan menentukan banyaknya potensi pelanggan PDAM. Dalam submodel ini, semakin banyak jumlah pelanggan akan meningkatkan cakupan pelayanan jika laju pertambahannya lebih besar dari laju pertumbuhan penduduk.

2. Sub model kapasitas pengelolaan

Sub model kapasitas pengolahan menjelaskan bagaimana volume air terjual dipengaruhi oleh kapasitas produksi, kapasitas terpasang, dan juga kehilangan air. Dalam submodel ini, besar kapasitas produksi dibatasi oleh kapasitas terpasang dan dipengaruhi oleh ketersediaan air baku serta jumlah pelanggan. Pada proses penyediaan air bersih, setelah diproduksi air bersih akan digunakan kembali untuk pemakaian produksi. Pada proses distribusi terjadi kehilangan air sehingga volume air terjual akan berkurang dari volume air terdistribusi. Selanjutnya, volume air terjual akan mempengaruhi ketersediaan air.

3. Sub model pasokan air bersih

Sub model pasokan air menjelaskan bagaimana potensi air baku dipengaruhi oleh perubahan guna lahan. Bertambahnya jumlah penduduk menyebabkan perubahan guna lahan dari lahan non-terbangun menjadi lahan terbangun. Hal ini berdampak pada menurunnya air yang dapat meresap ke dalam tanah (infiltrasi). Berkurangnya debit infiltrasi akan menyebabkan berkurangnya potensi air baku untuk kebutuhan penduduk. Potensi air baku juga dipengaruhi oleh debit air permukaan yang berasal dari sungai. Selanjutnya, potensi air baku berpengaruh terhadap kapasitas produksi PDAM.

\section{Perumusan Model Evaluasi}

Kontinuitas Layanan Air Minum

Berdasarkan hasil sintesa faktor diperolehbahwa faktor-faktor yang berpengaruh terhadap ketersediaan air bersih perpipaan adalah jumlah penduduk, tarif air bersih, kapasitas terpasang, tingkat kehilangan air dan kuantitas air baku.

Model dinamika untuk evaluasi dan peningkatan kontinuitas layanan air bersih dapat disusun dari tiga aspek, yaitu aspek pelanggan, kapasitas pengolahan, dan pasokan air. Penduduk dan tarif dapat digolongkan kedalam submodel pelanggan. Kapasitas terpasang dan tingkat kehilangan air dapat digolongkan kedalam submodel kapasitas pengolahan. Sementara kuantitas air baku dapat digolongkan ke dalam submodel pasokan air. 


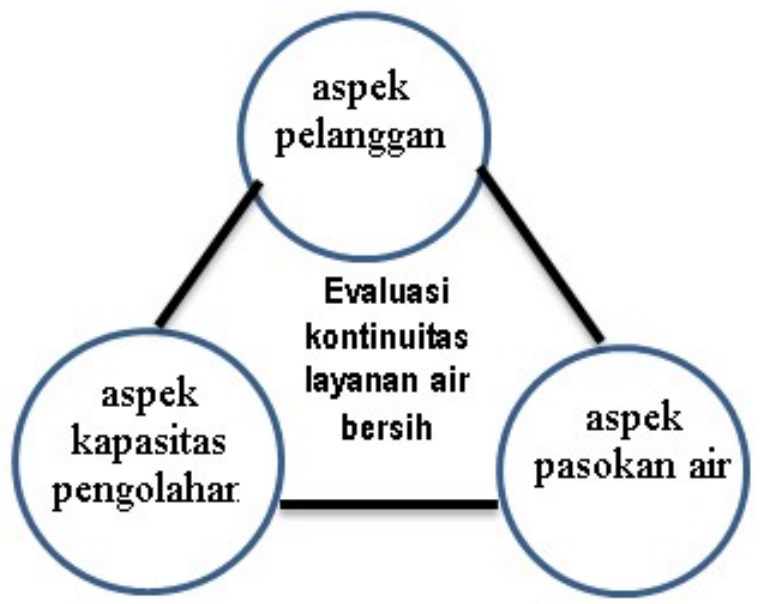

Gambar 3. Model dinamis evaluasi kontinuitas layanan air bersih

Berdasarkan hasil simulasi, pertambahan penduduk menyebabkan terjadi perubahanguna lahan dari lahan non-terbangun menjadi lahan terbangun. Hal tersebut berdampak pada berkurangnya potensi airbaku yang selanjutnya berpengaruh terhadap jumlah air yang dapat diproduksi. Kapasitas produksi selanjutnya akan mempengaruhi tingkat ketersediaan airmelalui volume air terjual. Ketersediaan air bersih yang mampu memenuhi setidaknya kebutuhan dasar pelanggan serta tarif yang masih dalam batas kesediaan membayar penduduk menyebabkan pertambahan pelanggan terus terjadi. Adapun jumlah pelanggan juga dipengaruhi pertambahan penduduk yang meningkatkan potensi pelanggan. Dengan demikian, ketiga sub model dalam model ketersediaan air bersih perpipaan dalam penelitian ini terhubung satu sama lain

Strategi Pelaksanaan Model Evaluasi Kontinuitas Layanan Air Minum

Dalam pembahasan ini, aspek efisiensi, kualitas pelayanan dan pengelolaan infrastruktur yang dianggap harus ditingkatkan; didiskusikan dalam focus group discussion. Hal ini dilatarbelakangi oleh asumsi bahwa perlunya peran pemerintah sebagai regulator dan enabler swasta sebagai operator dan provider pel;ayanan air bersih untuk air minum. Bagi pihak swasta, membutuhkan eksistensi dan kelonggaran waktu dalam hal pengelolaan selama periode tertentu. Sedangkan dalam privatisasi, swasta mengelola selamanya setelah menjadi hak milik (biasanya melalui penjualan aset).

Tabel 1. Model pengelolaan infrastruktur pengelolaan air bersih/air minum

\begin{tabular}{|c|c|c|c|}
\hline Pemerintah & Outsourching & $\begin{array}{c}\text { Kerjasama Pemerintah } \\
\text { Swasta }\end{array}$ & Privatisasi \\
\hline $\begin{array}{l}\text { Ditangani penuh } \\
\text { oleh pemerintah }\end{array}$ & $\begin{array}{l}\text { Manajemen } \\
\text { pengelolaan diambil } \\
\text { dari pihak luar (bisa } \\
\text { dari swasta) }\end{array}$ & $\begin{array}{c}\text { Pengelolaan diserahkan } \\
\text { kepada pihak swasta, asset } \\
\text { masih tetap milik pemerintah } \\
\text { yang dikembalikan setelah } \\
\text { pengelolaan selesai }\end{array}$ & $\begin{array}{l}\text { Pengelolaan murni } \\
\text { menjadi hak swasta. } \\
\text { Perubahan kepemilikan } \\
\text { aset (setelah dijual } \\
\text { kepada swasta) }\end{array}$ \\
\hline
\end{tabular}


Apabila sistem ini dapat berjalan dengan baik akan memberikan dampak positif secara tidak langsung pada iklim evaluasi dan dan peningkatan kontinuitas layanan air minum di lokasi penelitian. Pelayanan air bersih yang baik juga dapat memberikan kenyamanan, kesejahteraan, dan keindahan pada daerah tersebut.

Pengelolaan air bersih dengan memisahkan sistem dengan membagi menjadi beberapa bagian, yaitu :

1. Sumber air bersih dan konservasi

2. Sistem transmisi, Instalasi Pengelolaan Air (IPA), reservoir, dan pompa (operasi dan pemeliharaan)

3. Sistem disteribusi air bersi (operasi dan pemeliharaan)

4. Administrasi, misalnya pencatatan meteran air.

Regulasi yang mengatur dalam Kerjasama Pemerintah Swasta adalah, pertama, Keppres No. 7 Tahun 1998 tentang Kerjasama Pemerintah dan Badan Usaha Swasta dalam Pembangunan dan/atau Pengelolaan Infrastruktur. Kemudian diperjelas kembali oleh Perpres No. 67 tahun 2005 tentang Kerjasama Pemerintah dengan Badan Usaha dalam Penyediaan Infrastruktur. Kedua, adalah Keprres No. 81 tahun 2001 tentang Komite Kebijakan Percepatan Pembangunan Infrastruktur dengan diperjelas oleh Perpres No. 42 tahun 2005 tentang Kebijakan Percepatan Penyediaan Infrastruktur.

\section{Implikasi Penelitian}

1. Indikasi kebijakan yang terdiri dari: peningkatan kapasitas terpasang dan peningkatan ruang terbuka hijau; peningkatan kapasitas terpasang dan pengendalian kehilangan air; penyesuaian tarif air bersih; atau gabungan dari ketiganya. Intervensiintervensi tersebut dapat dilakukan dengan cara memperbaiki kerusakan jaringan pipa denganpemeriksaan berkala, studi penzoningan pipa layanan, penerapan sistem pelayanan bergerak, mengganti meteran air yang rusak, memasang meter air induk penajaringan pipa distribusi, serta melakukan sosialisasi kepada masyarakat untuk melaporkan kebocoran atau kerusakan meter air.

2. Kapasitas terpasang sebaiknya ditingkatkan dengan membangun infrastruktur yang baru atau memodifikasi kapasitas terpasang. Apabila upaya ini dapat meningkatkan kapasitas terpasang dan mengurangi tingkat kehilangan air secara bertahap, maka jumlah air terjual dapat ditingkatkan pula.

3. Mempertahankan ruang terbuka hijau yang sudah ada serta mengendalikan perubahan guna lahan dengan menerapkan peraturan zonasi serta mekanisme pengendalian pemanfaatan ruang lainnya. Selain itu dapat dilakukan pembangunan perumahan vertikal sebagai solusi terhadap meningkatnya kebutuhan hunian penduduk. ruang terbuka hijau dapat ditingkatkan dengan memanfaatkan lahan kosong yang potensial untuk dijadikan ruang terbuka hijau. Pengendalian perubahan guna lahan menjadi setengahnya dan peningkatan kapasitas air mengalir merupakan indikasi dari kemuingkinan dapat meningkatkatnya volume air terjual.

\section{KESIMPULAN}

1. Berdasarkan hasil sintesa faktor diperoleh bahwa faktor-faktor yang berpengaruh terhadap peningkatan kontinuitas layanan air minum di DKI Jakarta adalah jumlah penduduk, tarif air bersih,kapasitas terpasang, tingkat kehilangan air, dan kuantitas air baku. 
2. Model dinamika kontinuitas layanan air minum di DKI Jakarta dapat disusun dari tiga aspek, yaitu aspekaspek pelanggan, kapasitas pengolahan, danpasokan air. Penduduk dan tarif dapat digolongkan kedalam sub model pelanggan. Kapasitas terpasang dan tingkat kehilangan air dapat digolongkan kedalam sub model kapasitas pengolahan. Sementara kuantitas air baku dapat digolongkan kedalam sub model pasokan air.

3. Berdasarkan hasil simulasi, pertambahan penduduk menyebabkan terjadi perubahan guna lahan dari lahan non-terbangun menjadi lahan terbangun. Masalah ini berdampak pada berkurangnya potensi air baku yang selanjutnya berpengaruh terhadap jumlah air yang dapat diproduksi. Kapasitas produksi selanjutnya akan mempengaruhi tingkat ketersediaan air melalui volume air terjual. Kontinuitas akan ketersediaan air bersih yang mampu memenuhi setidaknya kebutuhan dasar pelanggan serta tarif yang masih dalam batas kesediaan membayar penduduk menyebabkan pertambahan pelanggan terus terjadi. Adapun jumlah pelanggan juga dipengaruhi oleh pertambahan penduduk yang meningkatkan potensi pelanggan. Dengan demikian, ketiga sub model dalam model ketersediaan air bersih akan menjamin kontinuitas layanan air minum di DKI Jakarta dan terhubung satu sama lain.

\section{DAFTAR PUSTAKA}

Ali Karnib. Evaluation of the quality of service of the water supply delivery in Lebanon. Article in Journal of Water, Sanitation and Hygiene for Development. March 2015. DOI: 10.2166/washdev.2014.057.

https://www.researchgate.net/public ation/275770045_Evaluation_of_the _quality_of_service_of_the_water_s upply_delivery_in_Lebanon

Dunn, William N. 1994. Analisis Kebijakan Publik. Edisi Kedua.Gadjah Mada University Press, Yogyakarta.

Gabriella Lockhart, William E. Oswald, Brian Hubbard, Elizabeth Medlin, and Richard J. Gelting. Development of indicators for measuring outcomes of water safety plans. Article in Journal of Water, Sanitation and Hygiene for Development. Published March 2014, 4 (1) 171-

181; DOI: 10.2166/washdev.2013.1

59.

http://washdev.iwaponline.com/cont ent/4/1/171

Gelting RJ, Delea K, Medlin E. A conceptual framework to evaluate the outcomes and impacts of water safety plans. Journal of Water, Sanitation and Hygiene for Development. 2012;2(2):103-111.

http://www.waterjustice.org/uploads/attac hments/whywaterprivatisationfails.p df.pdf

Lyman, R. Ashley. 1992. Peak and OffPeak Residential Water Demand dalam Water Resource Researches. 28(9): 2159-2167: American Geophysical Union.

Madanat, Samer. 1993. A Model of Household Choice of Water Supply Systems in Developing Countries dalam Water Resource Researches. 29(5): 609-615: American Geophysical Union.

Nancy Roberts et al. 1983 Introduction to Computer Simulation: A system dynamics modeling approach. Addison-Wesley. 
Nieswiadomy, Michael L. $1992 . \quad$ Thomas, R. M. 2001. Connectionism and Estimating Urban Residential Water Demand, Effect of Price Structure, Conservation and Education. 28(3): 609-615: American Geophysical Union. dynamic systems. In Recent Theories of Human Development. Thousand Oaks, CA: Sage. 